\title{
Effect of storage conditions, packing materials and seed treatments on viability and seedling vigour of onion (Allium cepa l.) seeds
}

\author{
J. B. Patel*, C. A. Babariya, Jyoti Sondarva, K. H. Ribadiya and V. J. Bhatiya \\ Department of Seed Science and Technology, Junagadh Agricultural University, Junagadh-362001 (Gujarat), INDIA \\ *Corresponding author. E-mail: jbpatelvasai38@gmail.com
}

Received: October 28, 2016; Revised received: February 8, 2017; Accepted: May 9, 2017

\begin{abstract}
The present investigation was carried out from July 2013 to July 2015, wherein $100 \mathrm{~g}$ of fresh quality seed of onion cv. GWO 1 was having high germination percentage and moisture content below 8 per cent. The treatment consisted of two storage conditions (C) viz., $C_{1}$ (Ambient temperature) and $\mathrm{C}_{2}$ (Cold storage at $7^{\circ} \mathrm{C}+2^{\circ} \mathrm{C}$ ); two packing materials $(P)$ viz., $P_{1}=$ Cloth $B a g$ and $P_{2}=$ Polythene Bag $(500$ gauge $=125 \mu)$, and five seed treatments (S) viz., $S_{1}=$ Control, $S_{2}=$ Carbendazim @ 2g/kg seed, $S_{3}=$ Mancozeb @ 2g/kg seed, $S_{4}=$ Thirum @ 3g/kg seed, and $S_{5}=$ Neem leaf powder @ 10g/ kg seed. After proper mixing or smearing the seeds as per the treatments, seeds were packed and stored as per treatments. Observations were recorded at 90 days interval on viability and vigour parameters. The results revealed that seed stored under cold storage $\left(7 \pm 2{ }^{\circ} \mathrm{C}\right)$ and in polyethylene bags $(500$ gauge) noted significantly higher values for all the characters even after two years of storage. All the treatment combinations of seed stored under cold storage gave more than 70 per cent germination (As per ISTA standard) even after two years of storage, of which, seed treated with thirum @ $3 \mathrm{~g} / \mathrm{kg}$ seed was the best treatment. Therefore, it can be concluded that seed of onion can be stored up to two year in cold storage packed in polyethylene bag without or with seed treatment without deterioration in germination and seedling vigour.
\end{abstract}

Keywords: Ambient, Cold storage, ISTA, Onion, Packing materials, Seed treatment

\section{INTRODUCTION}

Onion (Allium cepa L.) (Family: Amaryllidaceae, $2 n=16)$ is one of the major bulb crops of the world and important commercial vegetable grown all over the world. Most of the onion produced in India comes from the states of Maharashtra, Orissa, Gujarat, Karnataka and Uttar Pradesh. It is rich in vitamin ' $\mathrm{B}$ ' and has traces of vitamin ' $\mathrm{C}$ '. It also contains 11 per cent carbohydrates, 1.2 per cent protein, 86 per cent moisture and traces of minerals like iron and calcium. Its important characteristic is pungency, which is due to a volatile oil comprising as many as 50 known compounds.

Good seed is a basic input in vegetable production. Seed producers hold greater responsibility in maintaining genetically pure seeds and to preserve the quality of onion seeds from harvest to next sowing. Onion is an important vegetable crop. Its seed are short lived under ambient conditions (Doijode, 1987). Since, seed is a living entity and is subjected to various environmental stresses which affect the quality. In storage, the viability and vigour of the seeds not only vary from genera to genera and variety to variety, but it also regulated by many physico-chemical factors like moisture content, atmospheric relative humidity, temperature, initial seed quality, physical and chemical composition of seed, gaseous exchange, storage structure, packag- ing materials etc. (Doijode, 1988). Apart from this, fungi associated with stored seeds are mainly responsible for deterioration of quality and reduction in germination potential.

Seed treatment with chemicals is found to be more useful in storage for maintaining better seed quality up to one year in onion by suppressing the storage pests and fungi (Gupta et al., 1989). The safe and feasible approach is the treatment of seeds with botanicals, organics etc., which are safe, economical, cheap, ecofriendly in nature and non-toxic to man and animals. Among botanicals, using the castor, neem powder and neem oils are proved to be effective protectants against storage insects; they can reduce infestation and maintain the quality of the seed in terms of viability and vigour for longer period in storage (Kulkarni et al., 1988). As the seed is hygroscopic in nature, its quality is being affected due to variations in the environmental conditions viz., relative humidity, temperature, moisture content, gaseous exchange, packaging material etc. (Doijode, 1988). To combat these factors effectively storing the seeds in vapour proof containers like polythene bag, is found to be more useful in maintaining the desired quality of seeds for longer period (Gurmitsingh and Harisingh, 1992), unlike those stored in moisture pervious containers like cloth bag and gunny bag (Singh et al., 1988).

Therefore, the present investigation was conducted 
with and objective to identify the storage environment, suitable packing material and effective seed treatment to maintain higher seed viability and vigour of onion seeds for long term storage.

\section{MATERIALS AND METHODS}

The present investigation was carried out in laboratory of the Department of Seed Science and Technology, College of Agriculture, Junagadh Agricultural University, Junagadh from the July 2013 to July 2015, wherein $100 \mathrm{~g}$ of freshly harvested quality seed of onion cv. Gujarat White Onion 1 having high germination percentage and low moisture content (below $8 \%$ ) was taken for each repetition and for each combination of treatments. The treatment consisted of two storage conditions (C) viz., $\mathrm{C}_{1}$ (Ambient temperature) and $\mathrm{C}_{2}$ (Cold storage at $7{ }^{0} \mathrm{C} \pm 2{ }^{0} \mathrm{C}$ ); two packing materials (P) viz., $\mathrm{P}_{1}=$ Cloth Bag and $\mathrm{P}_{2}=$ Polythene Bag (500 gauge $=125 \mu$ ), and five seed treatments $(\mathrm{S})$ viz., $\mathrm{S}_{1}=$ Control, $\mathrm{S}_{2}=$ Carbendazim @ 2g/kg seed, $\mathrm{S}_{3}=$ Mancozeb@2g/kg seed, $\mathrm{S}_{4}=$ Thirum@3g/kg seed, and $\mathrm{S}_{5}=$ Neem leaf powder @ 10g / kg seed. The experiment was carried out using Completely Randomized Design (Factorial) repeated three times. After proper mixing or smearing the seeds as per the treatments, seeds were packed in two different packing materials and stored in two different storage conditions. Observations were recorded at 60 days interval on germination $(\%)$, root length $(\mathrm{cm})$, shoot length $(\mathrm{cm})$, seedling dry weight $(\mathrm{g})$, seed vigour index I, seed vigour index II and seed moisture content (\%). Germination test was carried out using paper towel technique as per the procedure given by ISTA (1999). Germinated seeds were counted on $8^{\text {th }}$ day and 10 germinated seedlings were selected from each replication of the treatment for calculating the seedling vigour index. The seedling vigour index (length and mass) was calculated by using the following formula (Abdul-Baki and Anderson, 1973). The shoot and root length of each of the 10 seedlings were measured in centimeters. Seedling dry weight $(\mathrm{mg})$ was measured for all the germinated seedlings after oven drying. The data were statistically analyzed as per the method of Cochran and Cox (1957) for Completely Randomized Design (Factorial).

\section{RESULTS AND DISCUSSION}

Effect of storage condition on seed quality parameters: The temperature maintained in the cold storage was $7 \pm 2{ }^{\circ} \mathrm{C}$ and relative humidity was around $80-90$ percent. The onion seeds packed in pervious containers and stored in cold storage gained moisture content and this is evidenced by rise in moisture content from initial moisture content of 3.90 to 4.66 per cent. This was due to prevalence of higher $\mathrm{RH}$ or vapour pressure and low temperature in cold storage. The seeds stored in ambient condition also gained moisture content and it is evidenced by rise in moisture content to 6.82 per cent from 5.68 per cent due to prevalence of higher vapour pressure. The relative humidity under ambient condition varied from 35 to 80 per cent during storage period. The seeds stored in cold storage $\left(\mathrm{C}_{2}\right)$ recorded higher germination compared to ambient condition throughout out the storage period of 24 months. Seeds stored in cold storage have retained the germination above certification standard up to 24 months during the storage, while seeds stored in ambient condition retained germination up to minimum seed certification standard $(70 \%)$ only for four months (Table 1$)$. Seeds preserved in the cold storage maintained higher seed quality because of lower respiration rate and metabolic activity as it is evidenced by higher germination ( 77.57 $\%$ ) at the end of 24 months of storage period. Ellis et al. (1991) have also observed higher germination up to three years in onion seeds, when the moisture content was maintained from6.0 to $6.8 \%$ (dry treatment) or 3.6 -3.7 (ultra dry treatment) and stored under a temperature of $2-20{ }^{0} \mathrm{C}$. Ellis et al. (1991), Garica and Perez (1985) and Nagaveni (2005) reported that onion seeds stored in the cold storage maintained higher vigour, which supports the present findings on seed vigour (Table 5 and 6). Alhamdan et al., 2011; reported that seeds of onion stored at $5{ }^{\circ} \mathrm{C}$ had the highest seed germination percentage and germination coefficient of velocity. Higher rate of germination is an indication of higher vigour. Seeds preserved in cold storage $\left(\mathrm{C}_{2}\right)$ recorded higher root length (Table 2), shoot length (Table 3), seedling dry weight (Table 4), seed vigour index (length) (Table 5) and seed vigour index (mass) (Table 6) compared to ambient condition $\left(\mathrm{C}_{1}\right)$ (laboratory condition). Seeds preserved in cold storage recorded higher root length, shoot length, seedling dry weight and seed vigour index (length and mass) mainly due to lower respiration rate and metabolic activity, which were governed by lower temperature during the storage period (Ellis et al., 1991; Garica and Perez, 1985 and Nagaveni, 2005 in onion; Balesevic-Tubic et al., 2010 in oilseed crops; Basavegowda and Hosamani, 2013 in chickpea; and Venge et al., 2016 in soybean).

Effect of packing materials condition on seed quality parameters: Seeds packed in cloth bag recorded numerically higher moisture content $(5.77 \%)$ compared topolythene bag $(5.71 \%)$ after 2 years of storage. Seeds packed in polythene bag $\left(\mathrm{P}_{2}\right)$ showed lower rate of increasing in moisture content, which indicated the impervious nature of this container (Table 7). Similar observations were made by Saxena (1994) in onion, tomato, okra and cabbage, Doijode (1995), Nagaveni (2005) and Mollah et al. (2016) in onion. Seeds packed in polythene bag recorded higher germination $(79.77 \%$ ), which is more than minimum seed certification standard for 24 months, while in cloth bag $(79.10 \%)$ only for 4 months (Table 1$)$. This 
J. B. Patel et al. / J. Appl. \& Nat. Sci. 9 (2): 1054 - 1067 (2017)

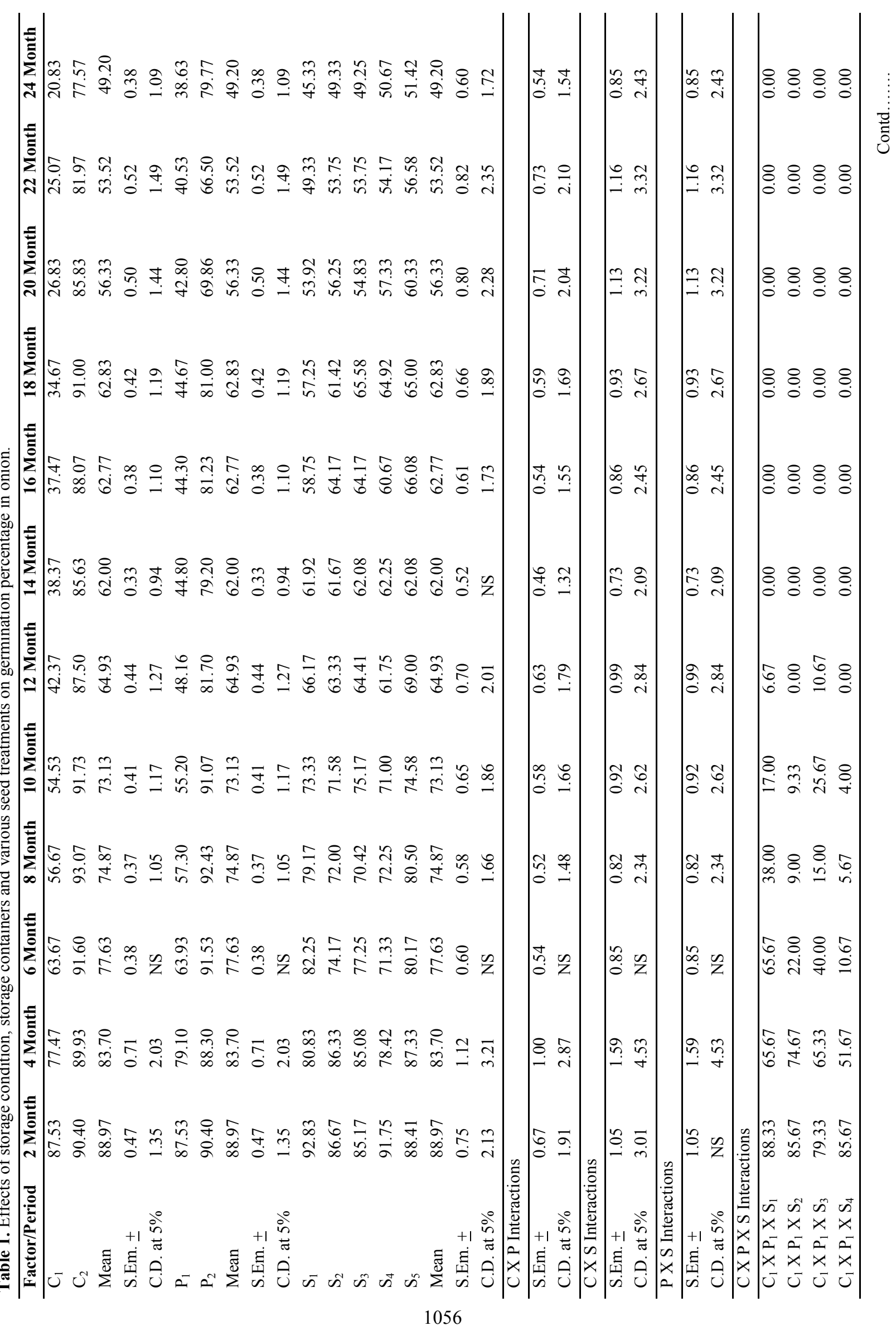


J. B. Patel et al. / J. Appl. \& Nat. Sci. 9 (2): 1054 - 1067 (2017)

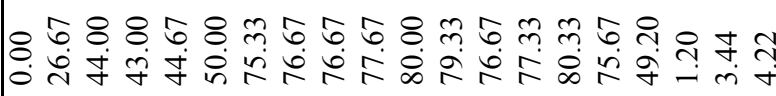

৪

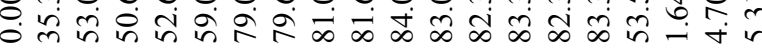

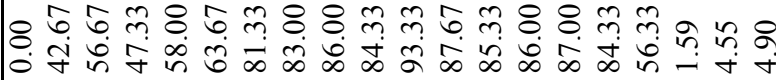

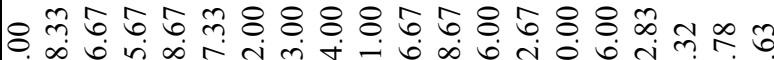

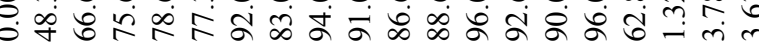

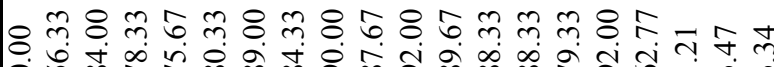

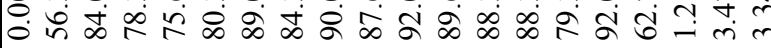

৪

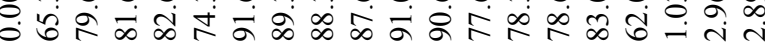

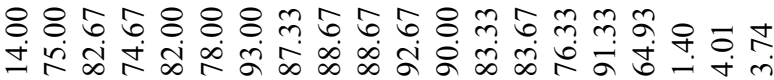

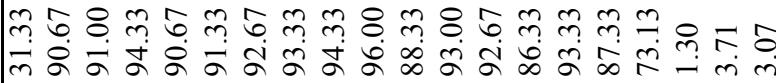

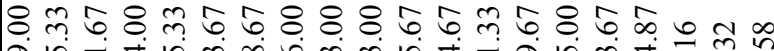

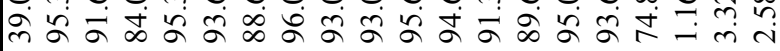

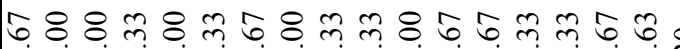
अं

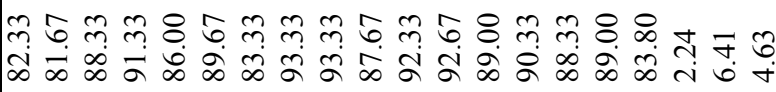

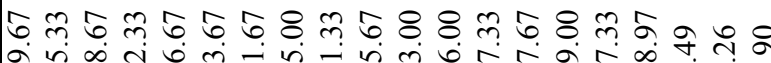
रूँ

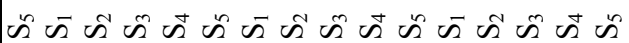
$x \times x \times x \times x \times x \times x \times x \times x$ $a^{-1} a^{2} a^{2} a^{2} a^{2} a^{-a} a^{-1} a^{-1} a^{2} a^{2} a^{2} a^{2} a^{2}$

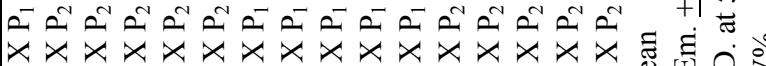

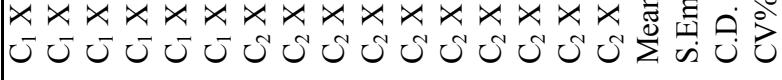

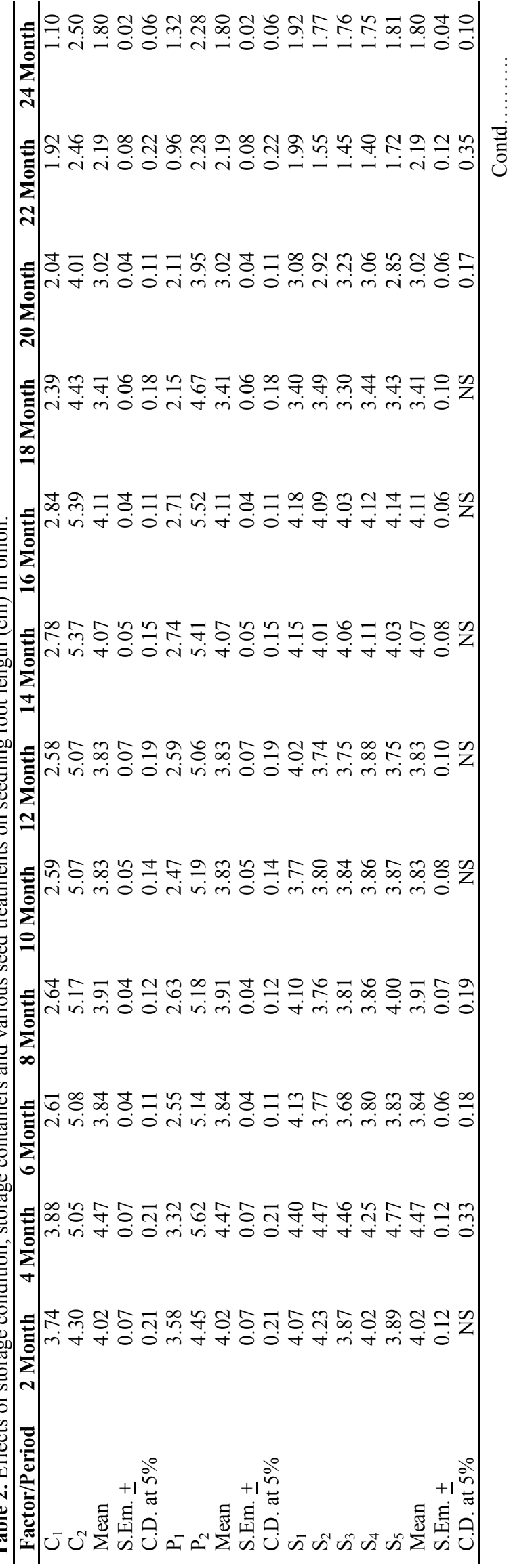


J. B. Patel et al. / J. Appl. \& Nat. Sci. 9 (2): 1054 - 1067 (2017)

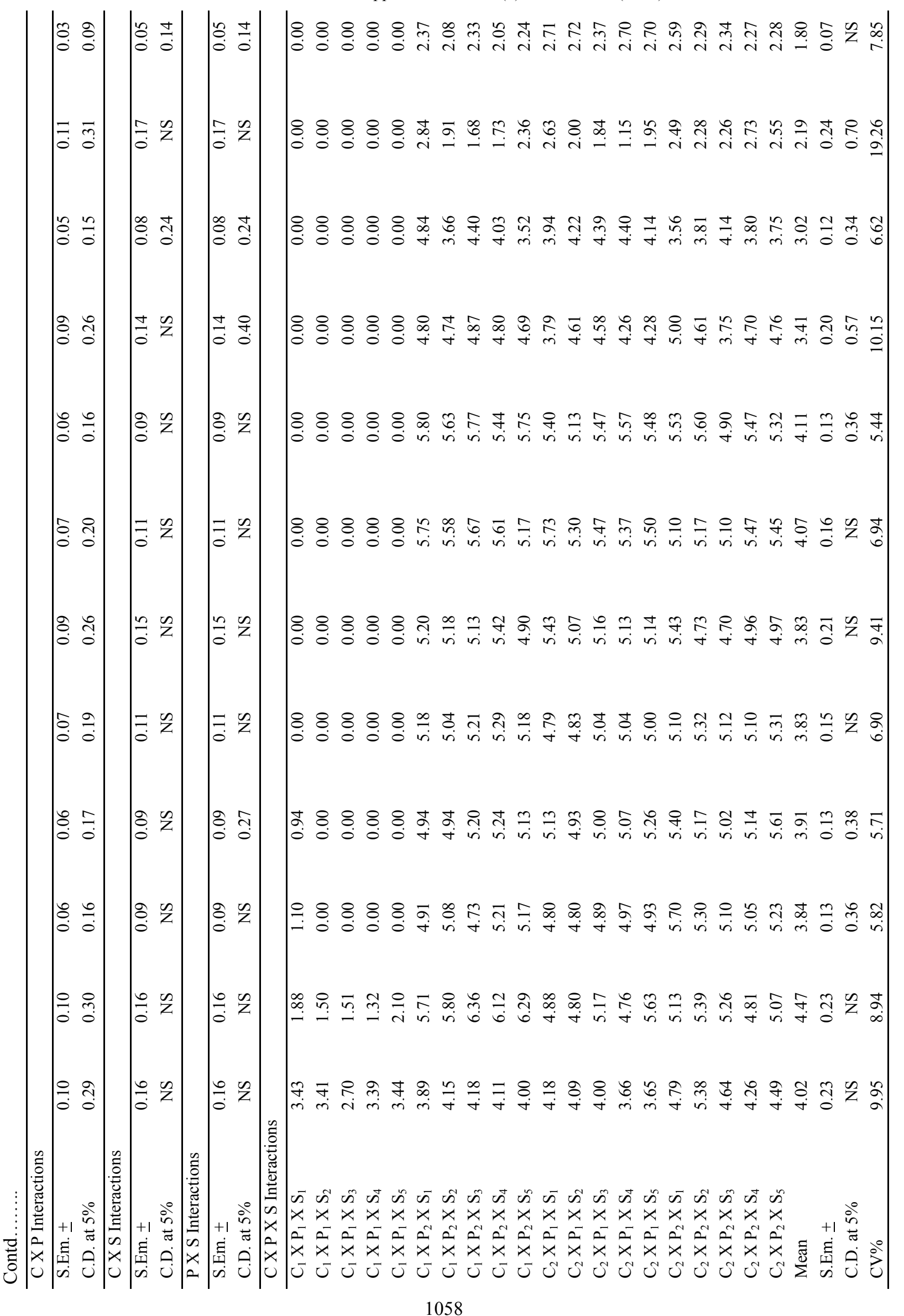


J. B. Patel et al. / J. Appl. \& Nat. Sci. 9 (2): 1054 - 1067 (2017)

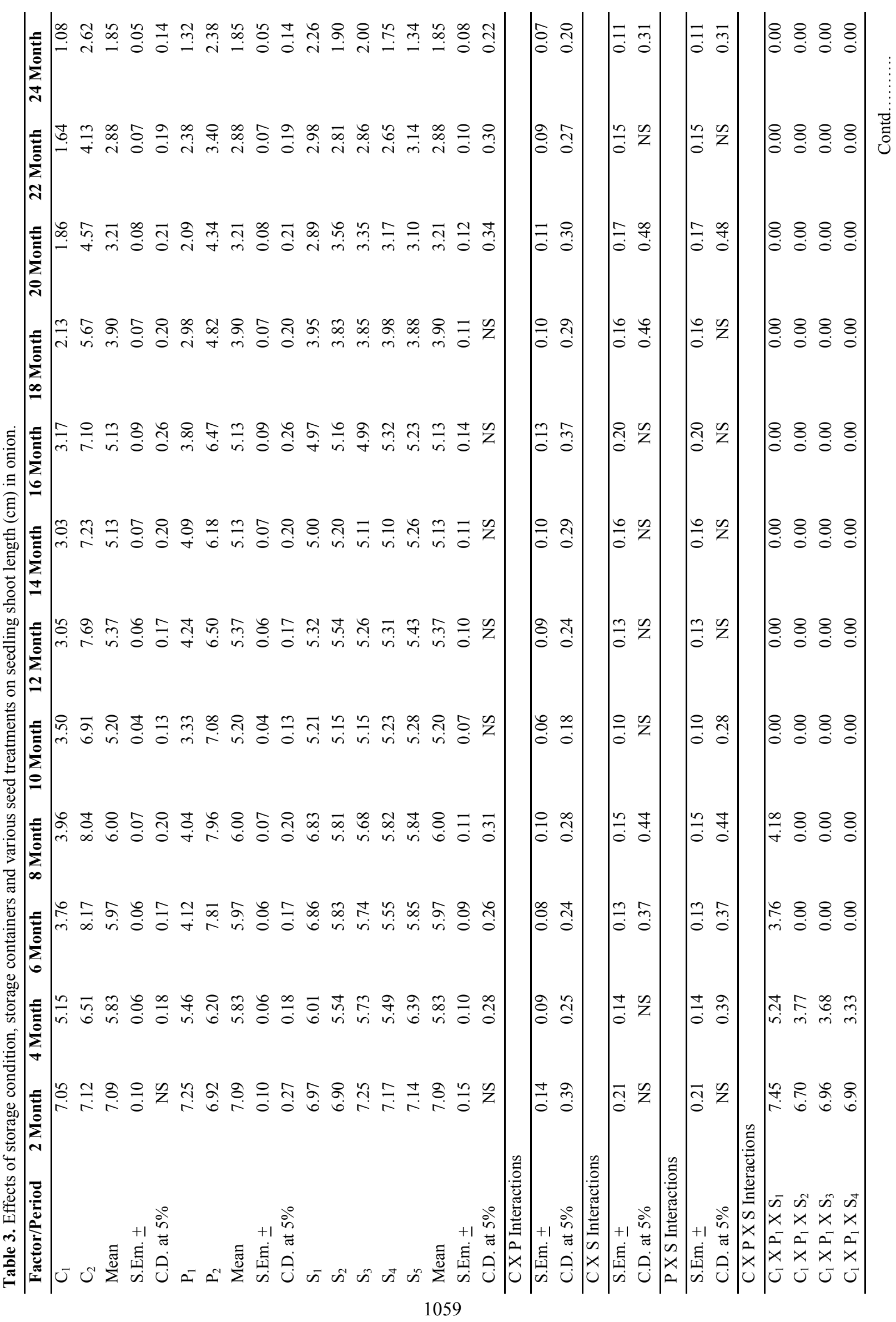


J. B. Patel et al. / J. Appl. \& Nat. Sci. 9 (2): 1054 - 1067 (2017)

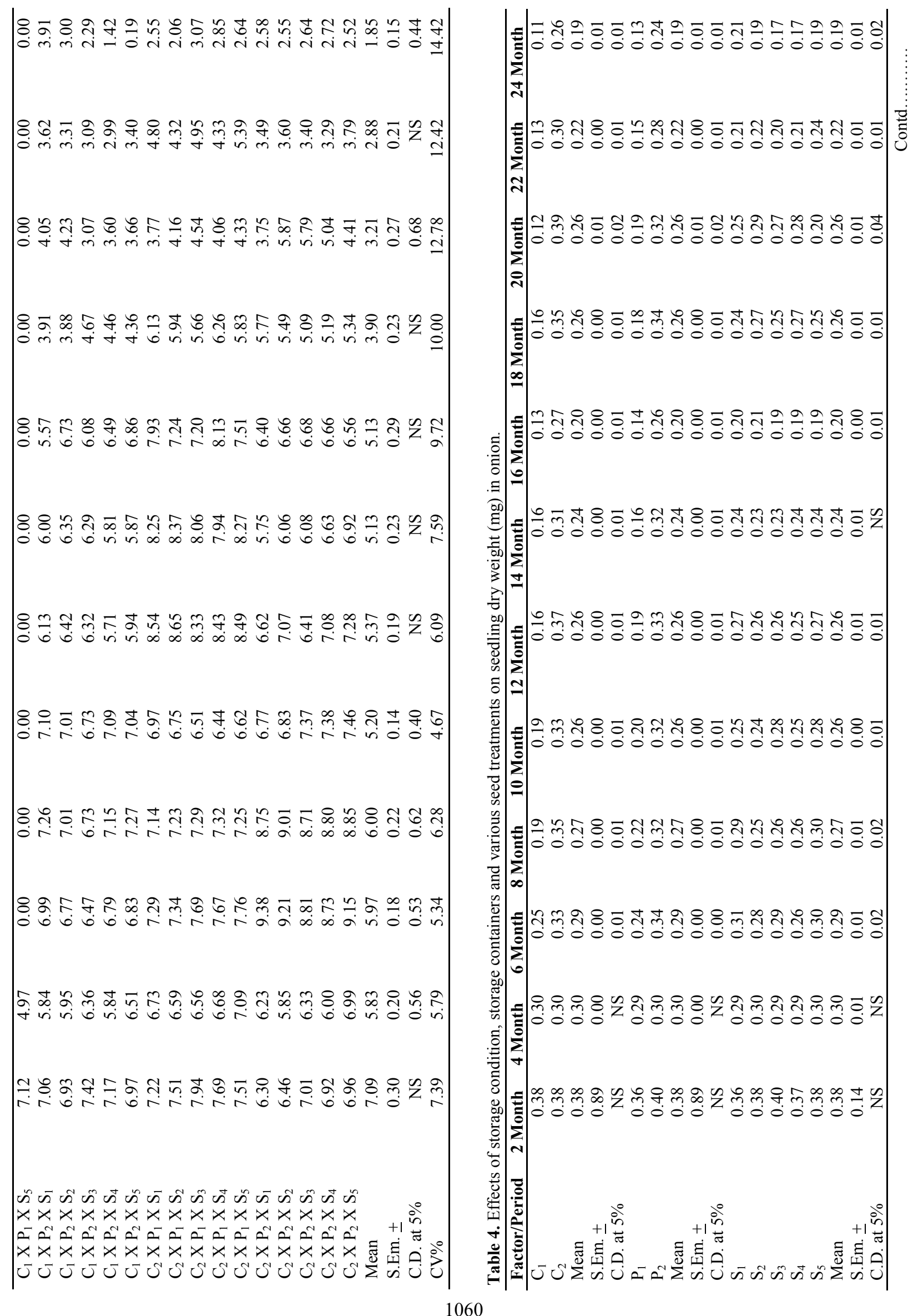


J. B. Patel et al. / J. Appl. \& Nat. Sci. 9 (2): 1054 - 1067 (2017)

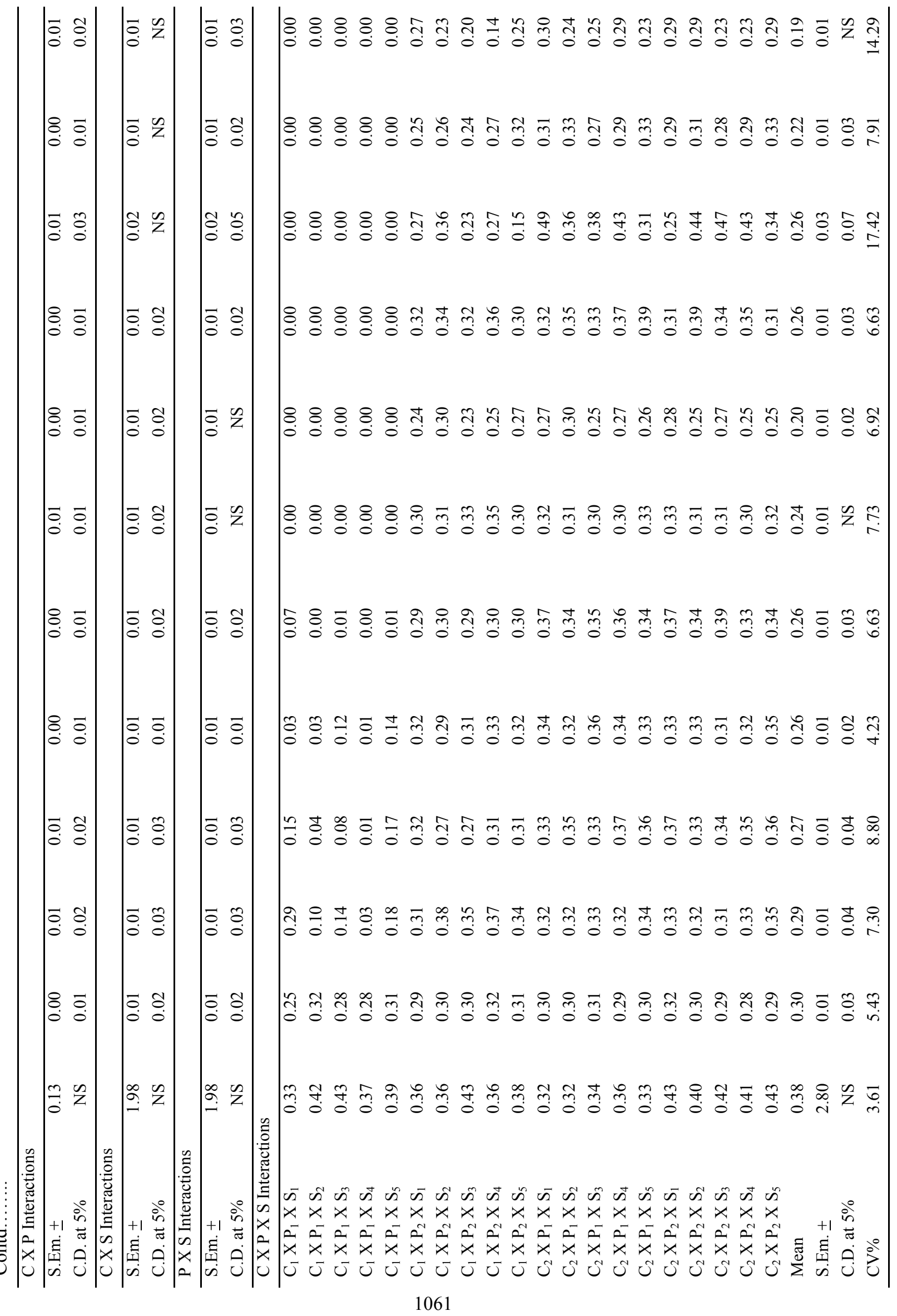


J. B. Patel et al. / J. Appl. \& Nat. Sci. 9 (2): 1054 - 1067 (2017)

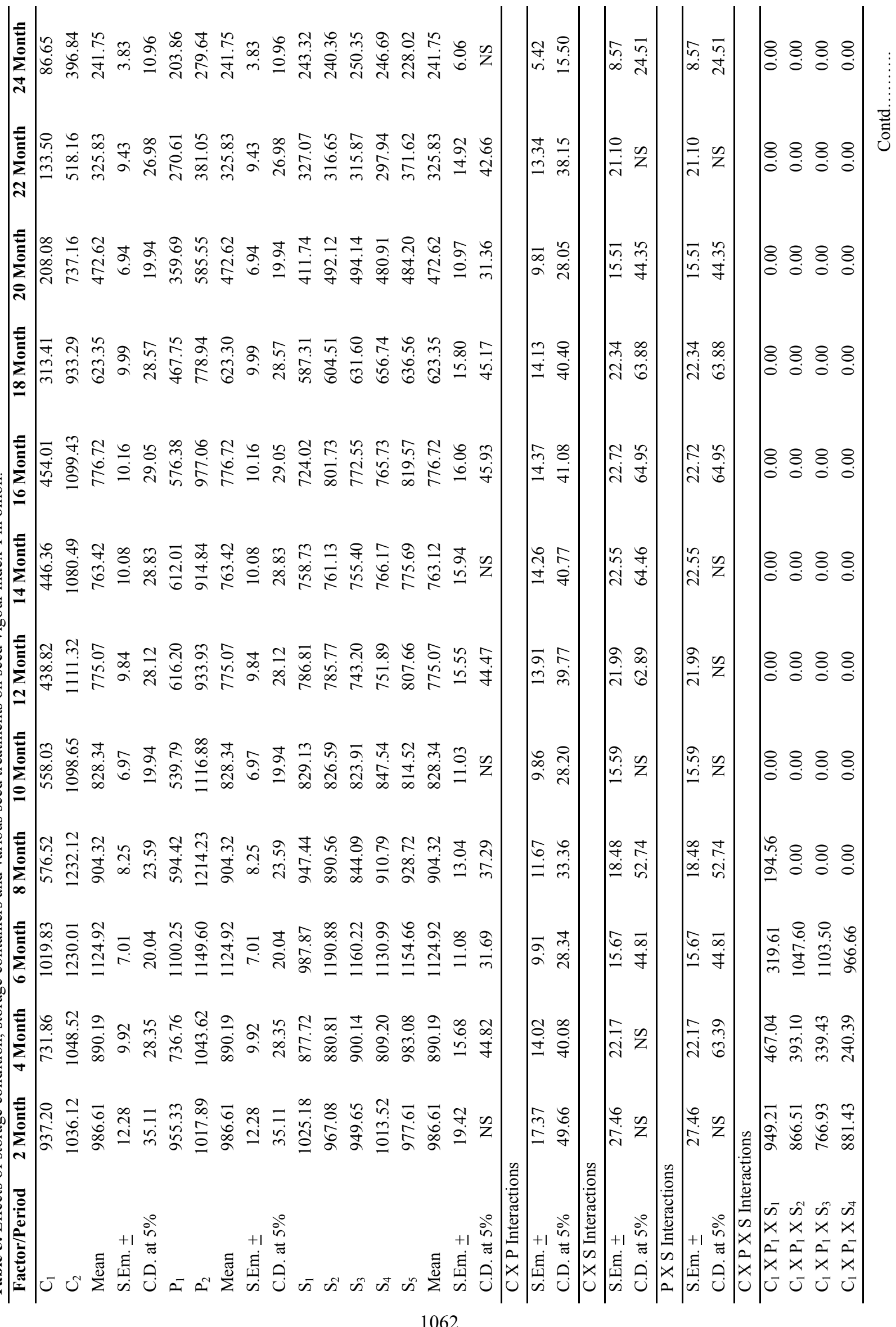




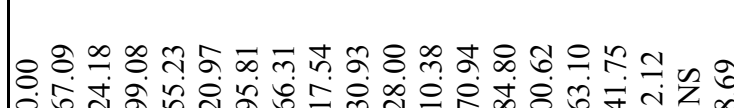

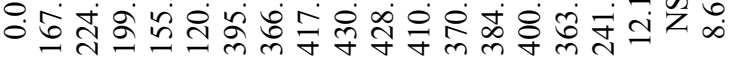

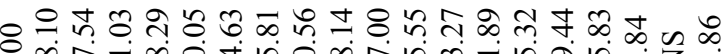

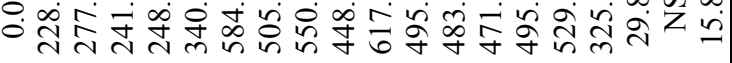

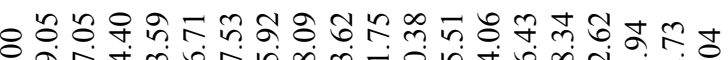

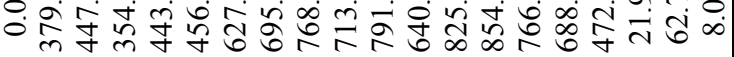

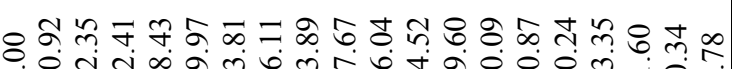

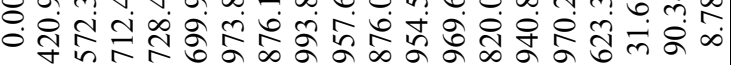

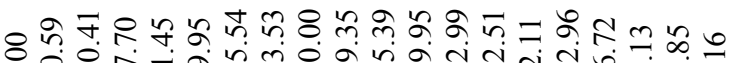

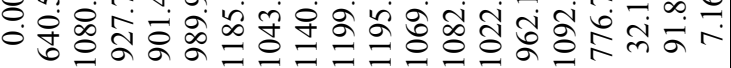

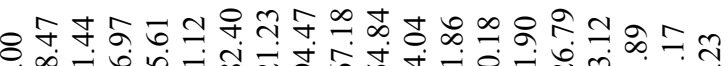

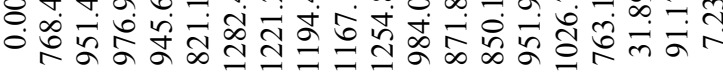

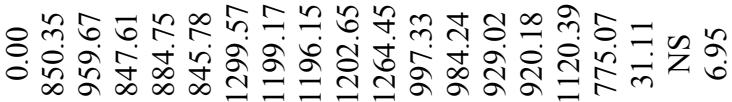

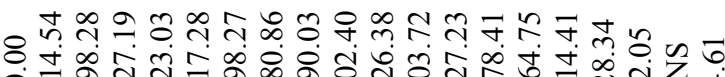

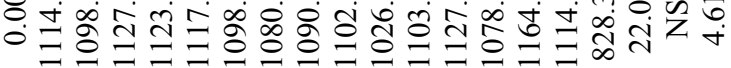

$\overrightarrow{0}$ o요

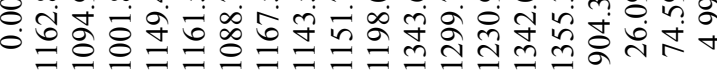

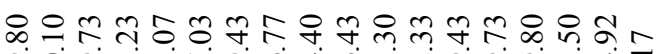

कें

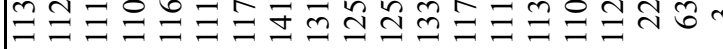

$\infty$ \& i ñ

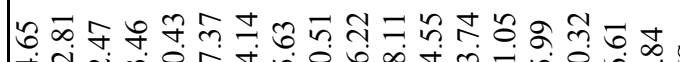
范出

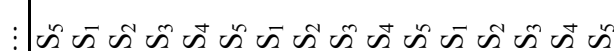
$\vdots \times x \times x \times x \times x \times x \times x \times x \times$

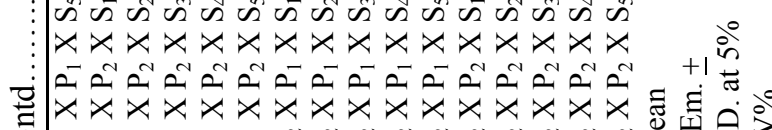

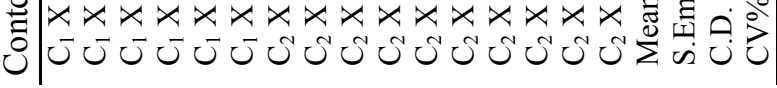

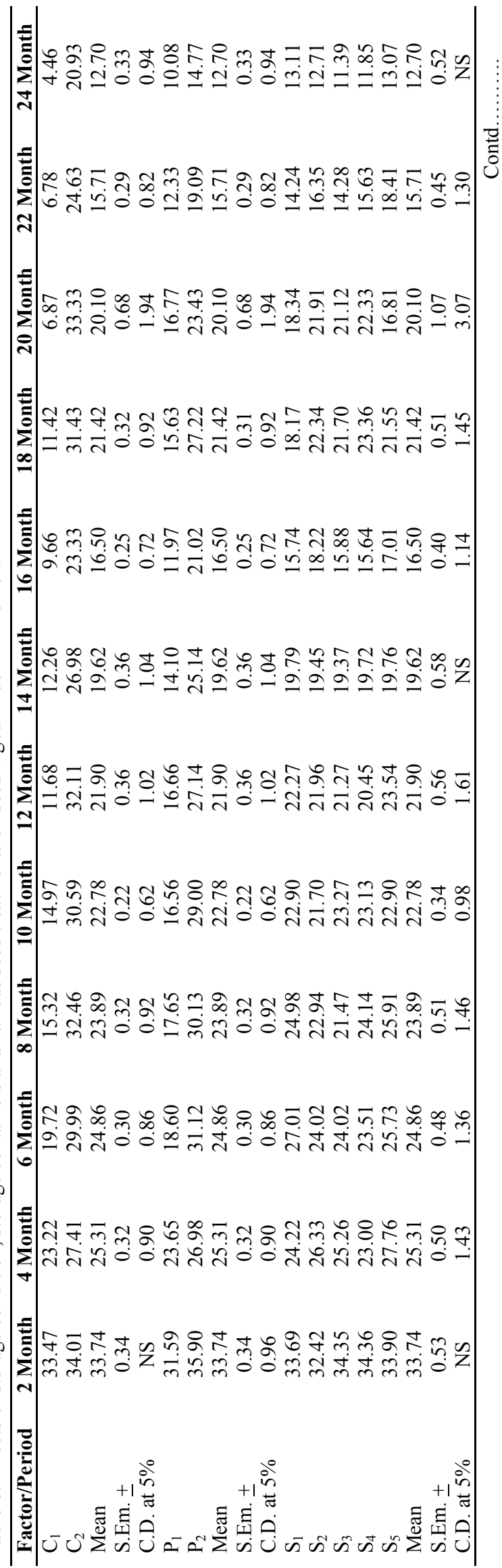


J. B. Patel et al. / J. Appl. \& Nat. Sci. 9 (2): 1054 - 1067 (2017)

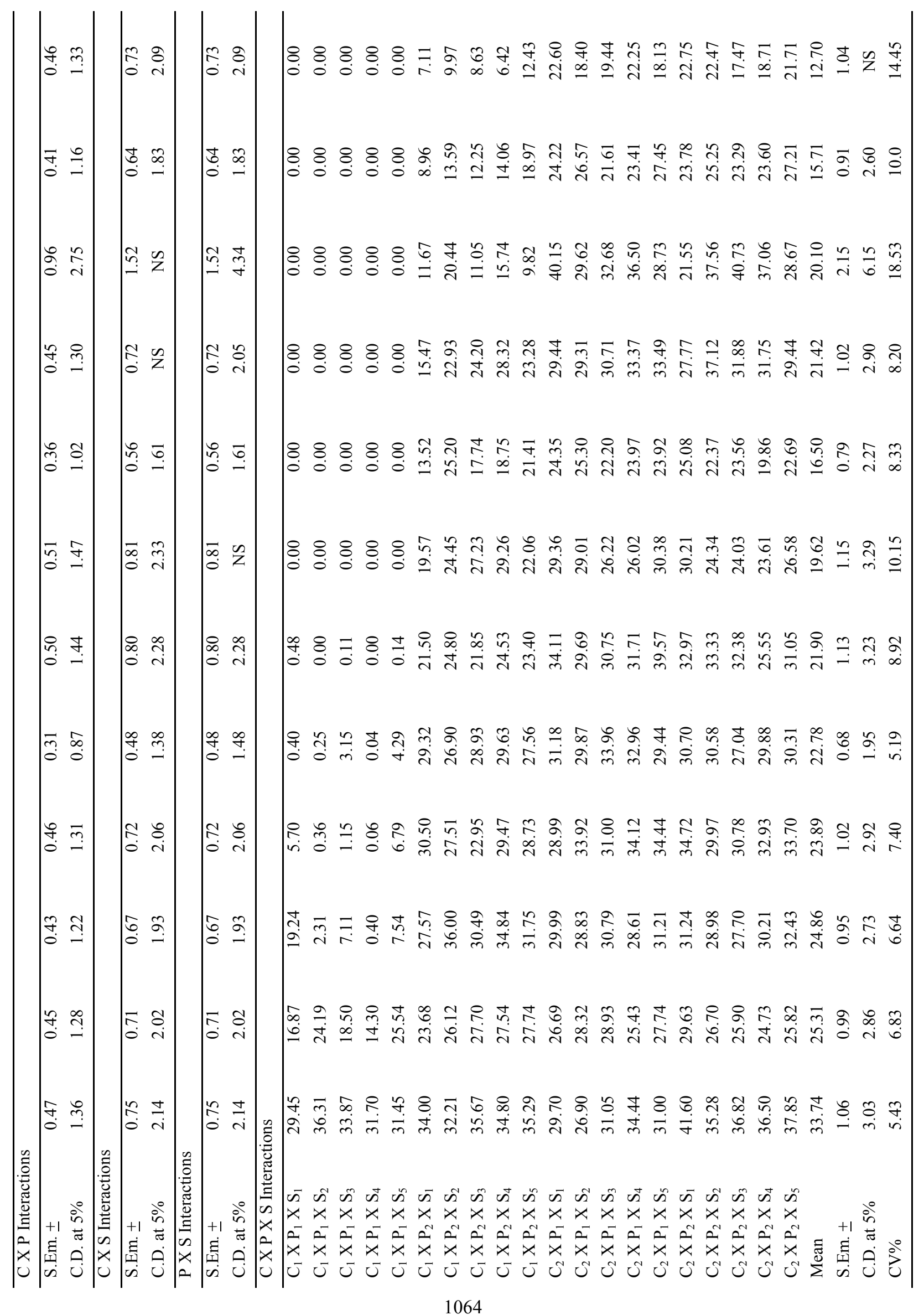


J. B. Patel et al. / J. Appl. \& Nat. Sci. 9 (2): 1054 - 1067 (2017)

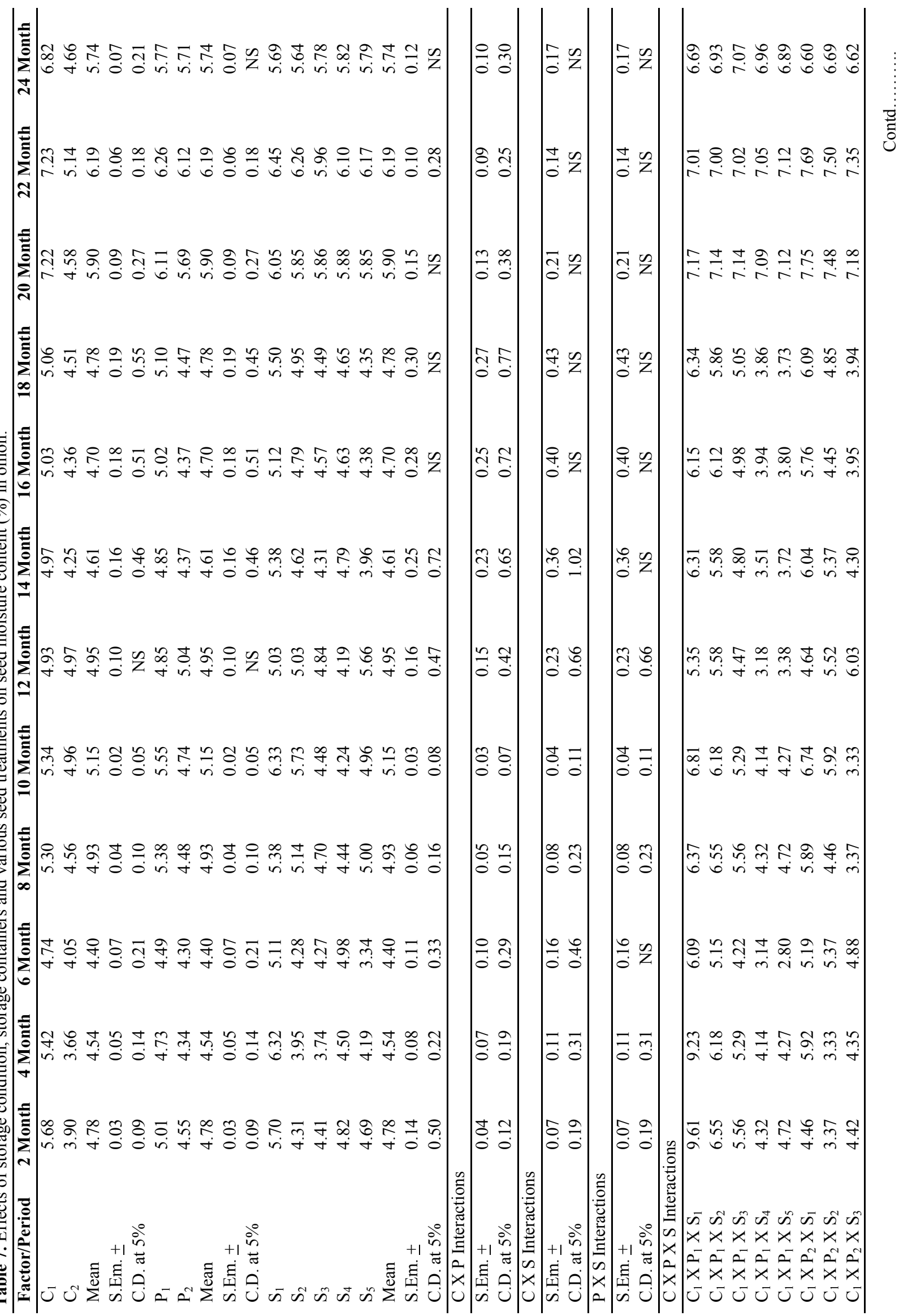




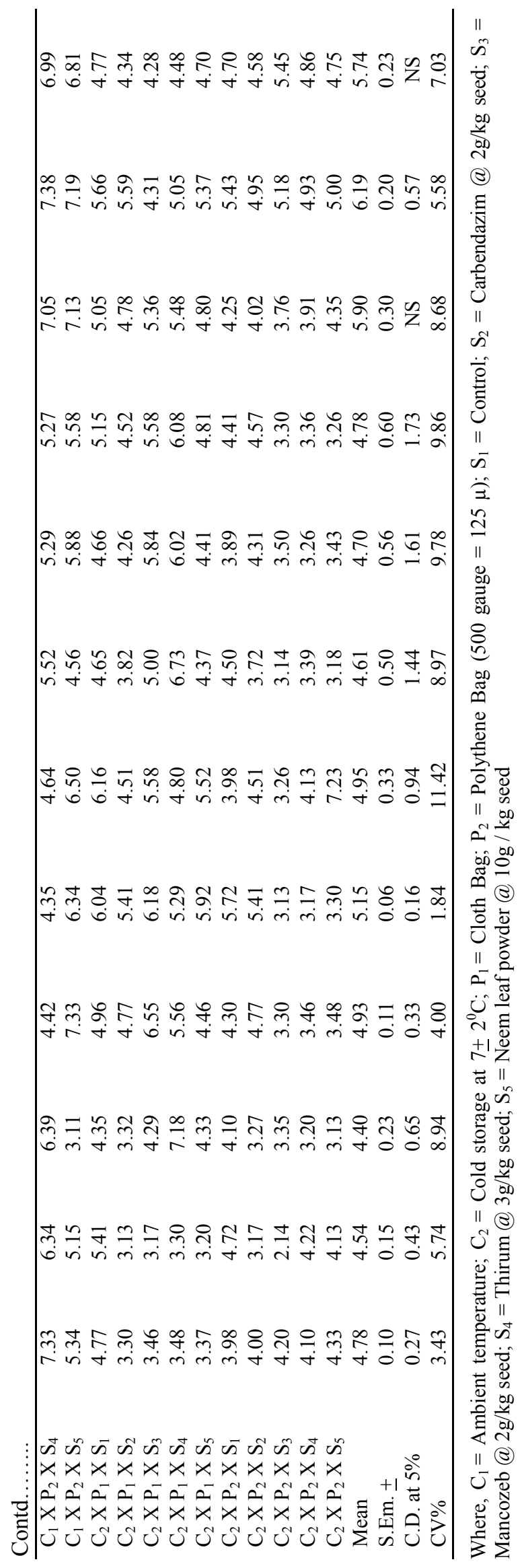

is in accordance with the findings of Doijode (1995), who have reported higher germination and vigour after seven years when onion seeds cv. Nasik dried to 6.5 per cent moisture content and packed in aluminium foil. Similar findings have been reported by Saxena et al. (1987) in onion, cabbage, radish, okra, cauliflower, pea and Padma, Nagaveni (2005) and Mollah et al. (2016) in onion. Seeds packed in polythene bag recorded higher root length (Table 2), shoot length (Table 3 ), seedling dry weight (Table 4), seed vigour index (length) (Table 5) and seed vigour index (mass) (Table 6) compared to seed packed in cloth bag. These results are in accordance with the reports of Doijode (1995), Saxena et al. (1987), Nagaveni (2005) and Mollah et al. (2016) in onion.

Effect of seed treatments on seed quality parameters: The effect of seed treatments was non-significant after two years of storage (Table 7). Among the seed treatments, on an average, after 2 years of seed storage, significantly higher values were recorded by all the seed treatments over the control. However, all the treatments including control showed germination of more than 70 per cent up to 10 months of storage. But all the treatment combinations of seed stored under cold storage gave more than 70 per cent germination (As per ISTA standard) even after two years of storage, of which, seed treated with thirum @ 3g/kg seed was the best treatment (Table 1). High germination is an indicator of high seedling vigour and because of that high seedling vigout index (length and mass) (Table 5 and 6) observed in treated seed as compared to control. This is in accordance with the findings of Singh et al.(1996) and Nagaveni (2005) in onion.

Interaction effect of storage condition, packing material and seed treatments on seed quality parameters: Germination and vigour index differed significantly due to interactions of storage conditions, packing materials and seed treatments. The treatment combinations of $\mathrm{C}_{2} \times \mathrm{P}_{2} \times\left(\mathrm{S}_{1} \times \mathrm{S}_{5}\right)$ recorded higher germination $(>70 \%)$ and vigour index. Higher germination and vigour index in these treatment combinations was mainly due to treating the seeds with compatible fungicide and it played an effectively role in inhibiting the storage microflora. packing materials like polythene bag acted as moisture entry barriers and also maintained the lower moisture content in the seeds. The results obtained under the present study are supported by the findings of Jagadish et al. (1994) and Nagaveni (2005) in onion.

\section{Conclusion}

It was concluded that onion seed may be stored in cold storage $\left(\left(7 \pm 2{ }^{0} \mathrm{C}\right)\right)$ condition packed with cloth bag or polythelene bag (500 gauge) with seed treatment (Carbendazim@2g/kg seed or Mancozeb@2g/kg seed or Thirum@3g/kg seed or Neem leaf powder@ $10 \mathrm{~g} / \mathrm{kg}$ seed) or without seed treatment for a period of 
2 years without deterioration in germination and seedling vigour.

\section{REFERENCES}

Abdul-Baki, A. A. and Anderson, J. D. (1973). Vigor determination in soybean seeds by multiple criteria. Crop Sci., 13: 630-633

Alhamdan, A. M., Alsadon, A. A., Khalil, S. O., WahbAllah, M. A., Nagar, M. E. and Ibrahim, A. A. (2011). Influence of storage conditions on seed quality and longevity of four vegetable crops. American-Eurasian J. Agric. \& Environ. Sci., 11(3): 353-359

Balesevic-Tubic, S., Tactic, M., Dordevic, V., Nikolic, Z. and Dukic, V. (2010). Seed viability of oil crops depending on storage conditions. HELIA, 33: 153-160

Basavegowda, G. S. and Hosamani, A. (2013). Effect of commercial cold storage conditions and packaging materials on seed quality of chickpea (Cicer arietinum L.). Global J. Sci. Front. Res. Agric. Vet., 13: 23 $-28$

Cochran, V. G. and Cox, G. M. (1957). Experimental Designs. New York, John Wiley and Hall Ltd., London, Pp. 293-296

Doijode, S. D. (1987). Onion seed quality in relation to seed deterioration under accelerated ageing conditions. Veg. Sci., 12: 56-63

Doijode, S. D. (1988). Effect of storage environment on brinjal (Sorghum melongena) seed viability. Progressive Horti., 20: 292-293

Doijode, S. D. (1995). Effect of silica gel and storage containers on viability and vigour in onion. Seed Res., 18: 163-165

Ellis, R. H., Hong, T. D., Astely, D. and Kraak, H. L. (1991). Medium term storage of dry and ultra dry seeds of onion at ambient and subzero temperature. Onion news letter for the tropics, 6: 56-58

Garica, A. G. and Perez, R. C. (1985). Factors which influence loss of germination of onion seed (Allium cepa $\mathrm{L}$.) during storage. Horticultura Mexicana, 1: 15-26

Gupta, R. P., Ushamehra, Pandey, U. B. and Mehra, U.
(1989). Effect of various chemicals on viability of onion seed in storage. Seed Res., 17(1): 99-101

Gurmitsingh and Harisingh (1992). Maintenance of germinability of soybean (Glycine max L.) seeds. Seed Res., 20: 49-50

ISTA (1999). International rules for seed testing. Seed Sci. Technol., Supplement Rules, 27: 20-25

Jagadish, G. V., Prasanna, K. P. R. and Ranganathaiah, K. G. (1994). Influence of storage conditions and containers on seed storability in onion (Allium cepa L.). Seed Tech. News, 24: 15

Kulkarni, S. G., Harode, S., Borikar, P. S., Puri, S. N. and Deshpande, S. D. (1988). Effect of containers and seed treatment on the storage of legumes. Seed Res., 16 (1): 121-122

Mollah, M. R. A.; Ali, M. A., Prodhan, M. Z. H., Rahman, M. M. and Alam, M. J. (2016). Effect of containers on storability of true seeds of onion. European J. Biometri. Pharmaceutical Sci., 3(1): 1-4

Nagaveni, P. K. (2005). Effect of storage conditions, packing materials and seed treatments on viability and vigour of onion seeds. M. Sc. (Agri.) Thesis (unpublished) submitted to University of Agricultural Sciences, Dharwad.

Saxena, O. P. (1994). Physiological and biochemical changes in relation to storage in some crop seeds. Seed Tech News, 29: 24

Saxena, O. P., Singh, G., Pakeeraiah, H. and Pandey, N. (1987). Seed deterioration studies in some vegetable seeds. Acta Hort., 215: 39-44

Singh, B., Singh, P., Vaish, C. P. and Katiyar, R. P. (1996). Effect of various fungicides on viability of onion (Allium cepa L.) seed in storage. Seed Res.,24(1): 61-63

Singh, S. N., Srivastava, S. K. and Agrawal, S. C. (1988). Viability and germination of soybean seeds in relation to pre-treatment with fungicides, period of storage and type of storage conditions. Trop. Agri. (UK), 65 (2): 106 $-108$

Venge, T., Ikyeleve, F. and Oko, J. O. (2016). Effect of packaging materials and storage condition on soybean germination and seedling vigour in Makurdi. Res. J. Seed Sci., 9(1): $1-4$ 